\title{
19th century earthquakes in Mexico: three cases, three comparative studies
}

\author{
América Molina del Villar \\ Centro de Investigaciones y Estudios Superiores en Antropologìa Social (CIESAS), Mexico D.F., Mexico
}

\begin{abstract}
This paper is a comparative study of the three strongest 19th century earthquakes in Mexico and their effects and impact mainly in Mexico City. The research is based on historical sources and previous investigations already published for two of the seismic events (8 March 1800 and 19 June 1858), with newly retrieved and analysed data for the 7 April 1845 earthquake. Primary and secondary sources include reports on damage to city buildings, streets and neighbourhoods and allowed a detailed analysis of the national and local effects, impacts and responses to each of the three earthquakes, whose comparison allows a better understanding of specific aspects related to the investigation of historical earthquakes in Mexico.
\end{abstract}

Key words earthquakes - Mexico - 19th century Mexico City

\section{Introduction}

Nineteenth century Mexico was seriously affected by three large earthquakes that occurred on 8 March 1800, 7 April 1845 and 19 June 1858 (García-Acosta and Suárez, 1996). While the 1800 and the 1858 ones have already been studied (Marquez, 2001; Molina, 2001), the 1845 one, which seems to have been the strongest, still lacks a thorough investigation. These three earthquakes happened during the first half of the 19th century, a period characterised by the Mexican transition from a colony (1521 onwards) to an independent nation (1821 onwards). This transition did not modify the way earthquakes were reported and recorded. The type of information, descriptions and even governmental responses were very similar in 1800, 1845 and 1858, which was due main-

Mailing address: Dr. América Molina del Villar, Centro de Investigaciones y Estudios Superiores en Antropologìa Social (CIESAS), Juarez 87, Tlalpan CP 14000, México, D.F., Mexico; e-mail: avillar@juarez.ciesas.edu.mx ly to the fact that the three earthquakes took place in the long period known as «The Age of Enlightenment», which is part of a process of political and social secularisation that in Mexico began in the 18 th century and whose effects were more strongly felt throughout the following century.

This paper is divided into three sections. First, we will present the political, social and economic context in which the three earthquakes occurred. In the second section, we will refer to the type of sources available for each event, whose information allowed us to know their effects and geographical reach. As the references are more abundant and more detailed for Mexico City than for the rest of the country, the third section is dedicated to material and human damage of each of the three earthquakes in the capital. Brief conclusions appear at the end of the paper, highlighting the main information obtained.

\section{Political, social and economic context of the three earthquakes}

In the late 18th century, the Bourbon regime carried out several reforms in its Colonies, whose main purpose was to undermine the 
power of the Church. The implementation of these changes took many years and had several effects, among which and associated with other factors, were the revolts which at last ended with the declaration of Mexico's Independence in 1821. The secularisation process as a whole culminated in the middle of the 19th century with the publication of the Mexican Laws of Reform, whose main contents are related to the definitive separation between State and Church, including the nationalisation of ecclesiastical properties and goods, the extinction of religious communities and the declaration of the cult of liberty.

As part of the «Enlightenment», the ideas related to progress and technological innovation gradually adopted scientific explanations of the origin of certain natural phenomena, giving up the religious ones. In dealing with earthquakes, these ideas and the struggle between the civil power and the Church spawned through publications that appeared from the middle of the 19th century on, mainly in journals, bulletins and books published by several scientific societies. By the same token and as a consequence of this transition to an ideological secularisation, a gradual separation between ecclesiastical and governmental responses can be seen. Processions organised together by civil and ecclesiastical authorities, as well as other religious manifestations dealing with the presence of earthquakes that were so common during previous centuries gradually ceased, notably after the 1845 earthquake.

While the enlightened ideas were proliferating throughout Mexico, several demographic, political and economic changes were happening. In 1800, Mexico was going through economic and social prosperity. In 1802 the capital had 137000 citizens; it was already larger than cities like New York, Philadelphia or Boston. One of the key interests of the authorities in these big cities was maintaining public works and cleaning the streets. After the 1800 earthquake, one of the viceroy's immediate actions was inspecting the districts and repairing material damage. In 1821, after Independence, there began a difficult period in Mexican history. The first half of the 19th century was a long period of physical and demographic stagnation, also visible in Mexico City. Struggles between political factions, military interventions, foreign invasions and coups d'état were coupled with epidemics and other disasters that restrained the growth of the capital. Between 1821 and 1870 the city's population remained around 200000 . The constant governmental changes and lack of financial resources interrupted several urban projects and the capital maintained during this time its colonial characteristics. The city government did not have enough money to attend to basic urban works, such as repairing aqueducts, drainpipes and bridges. Therefore the authorities had enormous difficulties to carry out the reconstruction works after the 1845 and 1858 earthquakes.

A few months before the 1845 quake occurred, there was a liberal political upheaval against the conservative forces, with the specific objective of prosecuting an old dictator, Antonio López de Santa Anna. The result of this movement was the change of president in December 1844, with the naming of an interim, José Joaquín Herrera. Herrera had to face the earthquake of April 1845 and carried out reconstruction works despite the economic difficulties and political problems. Inner conflicts were intensified by the conflict with the United States over Texas and California. The country was bankrupt and threatened by Spain, supported by internal groups that tried to impose a monarchy. Herrera's government was very brief; in December 1845 he was removed by another coup d'état headed by a general and supported by the monarchists (Diccionario, 1986; Vázquez, 2000).

The situation in Mexico did not change and hard times continued. The War of Reform, in which two political groups, liberals and conservatives, disputed power, had broken out a few months before the June 1858 earthquake. Conflicts and political tension concentrated in Mexico City. The fact that the federal powers resided in Mexico City continued to diminish its scarce budget. At the beginning of 1858, the conservatives took the city and established a conservative government, while liberals established a rival government in Veracruz, in the Gulf of Mexico. Thus, in June 1858 there was not only a civil war going on in Mexico, but two simultaneous governments. 
Table I. Main data for the 1800,1845 and 1858 earthquakes.

\begin{tabular}{|c|c|c|c|}
\hline & 1800 & 1845 & 1858 \\
\hline Date, hour & $\begin{array}{l}8 \text { March, } 8: 30 \text { a.m. } \\
\text { («some light movements } \\
\text { a few hours after the } \\
\text { earthquake»). }\end{array}$ & $\begin{array}{l}7 \text { April, } 3: 47 \text { p.m. } \\
\text { (aftershock on } 10 \text { April). }\end{array}$ & $\begin{array}{l}19 \text { June, 9:00 a.m. } \\
\text { (two more light aftershocks } \\
\text { on } 20 \text { and } 23 \text { June). }\end{array}$ \\
\hline Most damaged area & $\begin{array}{l}\text { Mexico City and } \\
\text { the States of Guanajuato, } \\
\text { Oaxaca, Puebla, } \\
\text { and Veracruz. }\end{array}$ & $\begin{array}{l}\text { Mexico City and the } \\
\text { the States of Aguascalientes, } \\
\text { Guerrero, Guanajuato, } \\
\text { Hidalgo, Jalisco, } \\
\text { Mexico, Michoacán, } \\
\text { Morelos, Oaxaca, Puebla, } \\
\text { Querétaro, San Luis Potosí, } \\
\text { Veracruz and Zacatecas. }\end{array}$ & $\begin{array}{l}\text { Mexico City and } \\
\text { the States of Colima, } \\
\text { Guanajuato, Guerrero, } \\
\text { Hidalgo, Jalisco, } \\
\text { México, Michoacán, } \\
\text { Oaxaca, Puebla, Querétaro, } \\
\text { San Luis Potosí, } \\
\text { Tlaxcala and Veracruz. }\end{array}$ \\
\hline Estimated magnitude $\left(^{*}\right)$ & $M 7.0$ & $M 8.0$ & $M 8.0$ \\
\hline
\end{tabular}

(*) According to Bravo et al. (1988).
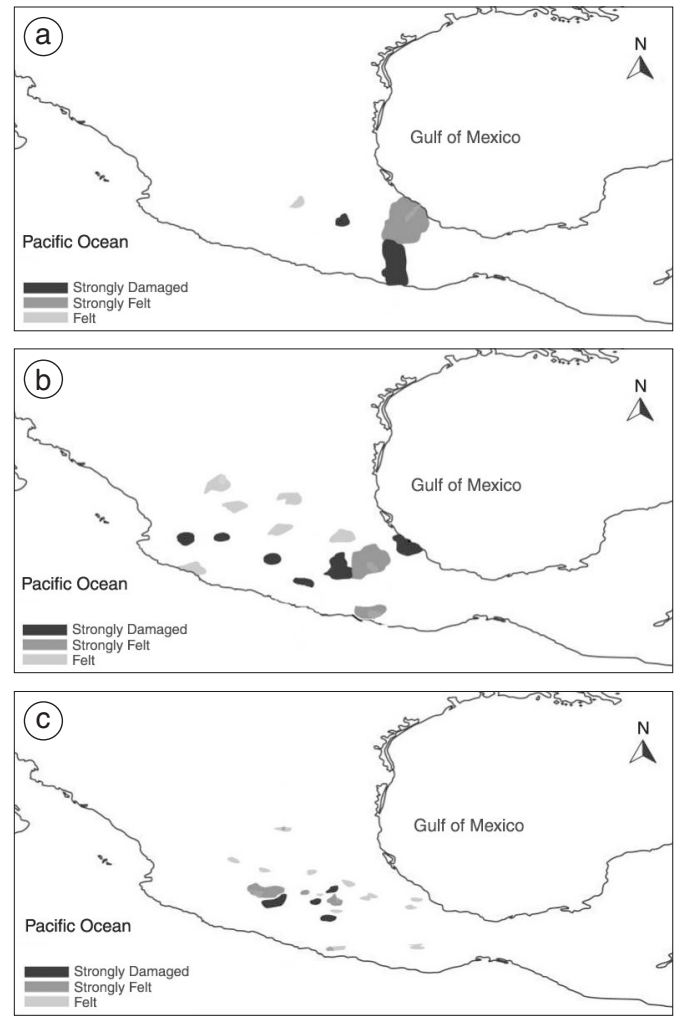

Fig. 1a-c. Areas and level of damage reported: a) 8 March 1800; b) 7 April 1845; c) 19 June 1858.

\section{Sources, effects and geographical reach}

Table I shows the main data related to the earthquakes studied, including current estimates of their magnitudes (Bravo et al., 1988), all of them 7 or above. Areas affected by each earthquake are shown in fig. 1a-c.

The three earthquakes affected Mexico City and nearby states located on the Pacific Coast (Oaxaca), in the centre of the country (Puebla) and in the Gulf of Mexico (Veracruz). Only a few reports of damaged localities are known for the 1800 event; but the records for the other two are more abundant. This fact is due to the sources available, specifically, newspapers. In 1800 there was only one newspaper, Gazetas de México, whose publication was erratic and mostly dedicated to what happened in Mexico City. When the other two quakes happened there existed several newspapers with correspondents distributed in some parts of the country whose reports offer more spatial information.

\subsection{March 1800 earthquake}

This event is now better known thanks to a study by Márquez published in 2001. As people used to name earthquakes according to the 
Christian calendar, this one is known as the «San Juan de Dios» earthquake because 8 March is the commemoration of this saint. Earth movements were reported in several localities at the Southern and Central parts of New Spain viceroyalty, mainly in those located at the Pacific and Gulf Coast, like Oaxaca city and the port of Veracruz. They were also felt in the valleys of Mexico and Puebla, as well as in Guanajuato, located 400 kilometres north from Mexico City.

The 8 March earthquake is the first in the García-Acosta and Suárez seismic catalogue (1996) with many references and detailed descriptions; in fact historical records on this earthquake are the richest throughout the colonial period. Nevertheless, the type of sources available are richer for Mexico City than for the rest of the country (table II).

For one of the most affected areas, the state of Oaxaca, information comes from historians books, local chronicles, diaries and articles written mainly by historians and scientists. There is no specific information available for the states of Puebla and Veracruz; for the state of Guanajuato it is even more scarce, for only the Diario de Bustamante whose editor Carlos María Bustamante, one of the best known publishers and historians in those days,

Table II. Sources for the 1800 earthquake.

\begin{tabular}{|c|c|c|}
\hline & New Spain & Mexico City \\
\hline Primary sources & $\begin{array}{l}\text { Bibliographical: Bustamante (1852), López } \\
\text { (1961). }\end{array}$ & $\begin{array}{l}\text { - Archives: AHDF (1800), AGNM (1800) } \\
\text { (mayors and architects reports). } \\
\text { - Newspapers: La Gaceta de México (1800). } \\
\text { - Bibliographical: Bustamante (1852), } \\
\text { Castillo (1875), López (1961). }\end{array}$ \\
\hline Secondary sources & $\begin{array}{l}\text { Bibliographical: Gómez (1864), Martínez } \\
\text { (1890), Sedano (1880). }\end{array}$ & $\begin{array}{l}\text { - Newspapers: El Siglo Diez y Nueve } \\
\text { (1858), Diario Oficial (1869). } \\
\text { - Bibliographical: Figueroa (1963), Gómez } \\
\text { (1864), Martínez (1890), Sedano (1880), } \\
\text { Waitz (1920). }\end{array}$ \\
\hline
\end{tabular}

Table III. Sources for the 1845 earthquake.

\begin{tabular}{|c|c|c|}
\hline & Country & Mexico City \\
\hline Primary sources & $\begin{array}{l}\text { - Archives: AGNM (1845), AHMM } \\
\text { (1845), APP (1845) (governmental and } \\
\text { ecclesiastical letters). } \\
\text { - Newspapers: El Siglo Diez y Nueve } \\
\text { (1845) and Diario Oficial (1845). } \\
\text { - Bibliographical: Adorno (1864), Böse } \\
\text { and García (1908), Malo (1948), } \\
\text { Ramírez and Reyes (1873), Romero } \\
\text { (1972), Waitz (1920), Zayas (1893). }\end{array}$ & $\begin{array}{l}\text { - Archives: AHDF (1845) (mayors and } \\
\text { architects reports). } \\
\text { - Newspapers: El Siglo Diez y Nueve } \\
\text { (1845), Diario Oficial (1845). } \\
\text { - Bibliographical: Adorno (1864), Böse } \\
\text { and García (1908), García Cubas (1904), } \\
\text { Gómez de la Cortina (1864), Malo } \\
\text { (1948), Ramírez and Reyes (1873), } \\
\text { Rivera (1883), Romero (1972), Waitz } \\
\text { (1920), Zayas (1893). }\end{array}$ \\
\hline Secondary sources & $\begin{array}{l}\text { Bibliographical: Amerlinck (1962), } \\
\text { Figueroa (1963), Orozco y Berra (1887), } \\
\text { Reséndiz (1988), Salas (1941). }\end{array}$ & $\begin{array}{l}\text { Bibliographical: Alfaro (1906), Amer- } \\
\text { linck (1962), Figueroa (1963), Galván } \\
\text { (1950), Mentz (1980), Orozco y Berra } \\
\text { (1887), Pérez (1904), Reséndiz (1988), } \\
\text { Salas (1941). }\end{array}$ \\
\hline
\end{tabular}


mentioned it was slightly felt there (Bustamante, 1852).

Figure 1a shows three areas with different levels and/or perceptions related to damage: 1) strongly damaged; 2) strongly felt, but no considerable material damage, and 3) felt, without reporting any damage. As can be appreciated, the most affected areas were located in Mexico City and in La Mixteca and La Cañada regions in Oaxaca.

According to an earthquake chronology written almost one century later (Martínez, 1890), in those areas the earthquake caused some damage.

\subsection{April 1845 earthquake}

It is amazing that this earthquake, considered by Mexican seismologists as the strongest among those that occurred throughout the 19th century even similar or perhaps stronger than that of 19 September 1985, has not deserved more investigation up to now. According to recent estimates (Bravo et al., 1988), the 1845 earthquake had a magnitude similar to that of the September 1985 earthquake: 8 or more.

This earthquake was felt with great intensity in Mexico City and in some localities of the states of Michoacán and Jalisco. As the 1985 earthquake, the epicentre of the 1845 one was located in the coast of Guerrero, in the Pacific Ocean.

Unlike the scarce press information for the 1800 earthquake, newspapers and archival sources provide detailed information on the effects of the 1845 event in the country as well as in Mexico City (table III), which makes it one of the best documented for that century. The novelty in this case was that the district reports about damage were published in the newspapers El Siglo Diez y Nueve (1845) and in the Diario Oficial (1845) which allows us to compare the information coming from two primary sources that recorded it.

Besides reports on damage, sometimes newspapers published edicts or decrees which help to analyse the response of government and society in face of these great earthquakes.

The 7 April earthquake was strongly felt and caused damage in Mexico City as well as in several Mexican States (table I and fig. 1b) covering areas in the central part of the country spreading from the Pacific to the Atlantic coasts. More specific data is available for the cities of Morelia (Michoacán), Guadalajara (Jalisco), Puebla (Puebla), Orizaba (Veracruz), Oaxaca (Oaxaca) and Guanajuato (Guanajuato). One of the most affected areas was Huamuxtitlán, where no building was left standing, nevertheless no deaths were reported. This town is located in the State of Guerrero whose western limit is the Pacific Coast, where the epicentre was located (Bravo et al., 1988).

Aftershocks were reported on the following day, and on 10 April in Mexico City and the States of Oaxaca, Puebla and Morelos.

Figure 1b shows the vast area affected by this quake using the same damage classification used for fig. 1a according to effects and impact on buildings and among the population: 1) strongly damaged: severely damaged areas, with collapsed buildings or temples, public buildings and houses at risk of collapsing; 2) strongly felt: areas with slight or imperceptible damage such as cracks, even though the movement was strongly felt; 3) felt: areas with no damage, where the main quake and its aftershocks were slightly or not felt at all.

\subsection{June 1858 earthquake}

This earthquake, named the «Santa Juliana», is best known after the study by Molina (2001). For this event there are dozens of references with details on its effects and impact in the capital city as well as outside it, even in small towns (García and Suárez, 1996). The latter, unmentioned in newspapers, were found in the archives of the Michoacán bishopric, among which the magnificent ecclesiastical archives include letters that the priests of several towns sent to the bishop of Michoacán describing the damaged ceilings, bell towers and façades of their churches. Other primary sources like newspapers also offered a large number of records from outside the capital city (table IV).

The press made several references to this earthquake, highlighting its impact outside the capital city. According to newspapers, the cities 
Table IV. Sources for the 1858 earthquake.

\begin{tabular}{|c|c|c|}
\hline & Country & Mexico City \\
\hline Primary sources & $\begin{array}{l}\text { - Archives: APP (1858), AHCMR } \\
\text { (1858, 1859), AHMM (1858) (ecclesi- } \\
\text { astical letters and council sessions). } \\
\text { - Newspapers: El Siglo Diez y Nueve } \\
\text { (1858). } \\
\text { - Bibliographical: Romero (1972). }\end{array}$ & $\begin{array}{l}\text { - Archives: AHDF (1858) (mayors and } \\
\text { architects reports). } \\
\text { - Newspapers: El Siglo Diez y Nueve } \\
\text { (1858). } \\
\text { - Bibliographical: García Cubas (1904) } \\
\text { Gómez de la Cortina (1864), Malo } \\
\text { (1948), Ramírez and Reyes (1873), } \\
\text { Rivera (1883), Waitz (1920). }\end{array}$ \\
\hline Secondary sources & $\begin{array}{l}\text { Bibliographical: Munguía (1976), } \\
\text { Orozco y Berra (1887), Zayas (1893). }\end{array}$ & Bibliographical: Orozco y Berra (1887). \\
\hline
\end{tabular}

most affected besides Mexico City were located in the states of Michoacán, Jalisco, Guerrero, Mexico and Hidalgo (table I and fig. 1c), with reports of collapse of temples, houses and buildings. The earthquake was strongly felt in other localities of Michoacán and Guerrero, though no information on economic damage is available. One of the most affected towns was Pátzcuaro in Michoacán, where the parish church showed severe damage, previously affected by the 1845 earthquake; its towers collapsed and their reconstruction took many years. In fact the only reference of deaths caused outside Mexico City is for Pátzcuaro, where 21 corpses were found, 5 of them at the parish church (APP).

Other towns reported slight damage and only minor economic losses, like: Iguala (Guerrero), Toluca and Texcoco (State of Mexico), San Luis Potosí (San Luis Potosí), Pachuca (Hidalgo), Querétaro (Querétaro), Tlaxcala (Tlaxcala) and Oaxaca (Oaxaca).

\section{Effects and impact in Mexico City}

Tables II, III and IV show that for the three studied earthquakes, the majority of historical references coming from archives, bibliography or newspapers, primary as well as secondary in origin, refer to the capital of the country. Furthermore, archival records include file reports prepared by the mayors, who were in charge of surveying buildings street by street and house by house. These reports provide the richest da- ta and most detailed information on the type of damage caused in Mexico City, and made possible the construction of maps for the 1800 and the 1858 quakes identifying the type of damage in each street and in each building (Márquez, 2001 and Molina, 2001).

\subsection{0}

By the end of the 18th century, Mexico City was divided into eight major districts in order to better administer power and public affairs. In each district the mayor was in charge of several tasks such as the security and well-being of the population, as well as attention in case of disaster, such as epidemics or earthquakes. Whenever an earthquake occurred, the mayor, with the help of architects, councillors and the people in charge of each block, would report the damage caused. The 1800 earthquake was the first during the late colonial period to be described in these reports.

Figure 2, originally published by Márquez (2002) shows the damage caused by this earthquake in the eight major districts Mexico City was divided into. These districts are marked in fig. 2 with Roman numerals following the code used in the original documents. After Márquez (2001) another code is introduced in this figure to identify six different levels of damage.

The 1800 earthquake affected 27 buildings in Mexico City, located mainly in the first four major districts. The main public square, includ- 


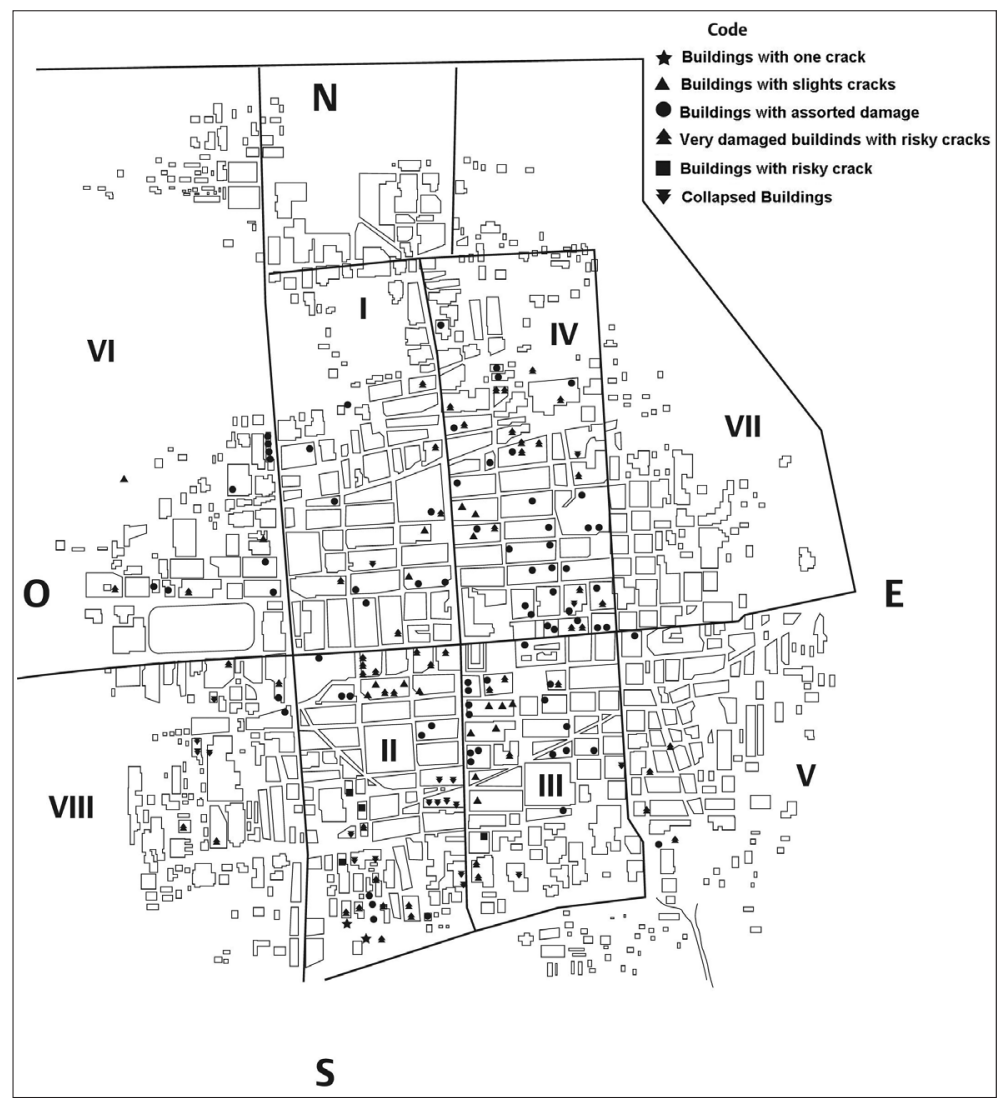

Fig. 2. Effects of the 8 March 1800 earthquake in Mexico City.

ing the Cathedral, the National Palace (federal government) and the Town Hall was at the intersection of these four districts. Many rich people lived there, and their houses were next to commercial and religious buildings, including convents, churches and religious schools. Most damaged buildings were located precisely in these four districts. A general balance of the areas and buildings affected by this quake shows, as can be seen in fig. 2, that the most damaged area was the city centre, mainly north, south and south-westwards of the Cathedral, corresponding to districts II, III and IV. This area produced more detailed descriptions because the majority of the population and important public, religious and commercial buildings were located here (AGNM, Obras Públicas and Correspondencia de Virreyes, 1800). Districts I, V, VI, and VIII were not as severely affected; nevertheless there were reports related to ruined buildings and collapsed walls, cracks in public buildings and houses, as well as damage to drainpipes and archways.

In spite of the severe damage, it is interesting to note that no human losses were reported.

\subsection{5}

As stated before, a detailed study of the effects of the 1845 earthquake in Mexico City, as well as its mapping, has yet to be carried out, 
although it is one of the best documented events in Mexican seismological history (table IV). Here is a first approach to a future, deeper case study, such as those for the 1800 and 1858 events, already published (Márquez, 2001 and Molina, 2001).

Around the middle of the 19th century the most important buildings were still located in Mexico City's first four districts. The 1845 event was popularly known as «the earthquake of Santa Teresa», as it collapsed the dome of the church of Santa Teresa la Antigua located in district IV. There are reports of 62 damaged public or religious buildings as well as 127 damaged houses, rooms and neighbourhoods (vecindades) in the first four districts. These are amazing numbers compared to the 27 damaged buildings reported in 1800 in the same area, even considering the estimated magnitude is higher, but there were also more people and more buildings there than in 1800, and hence greater exposure.

Archives and newspapers offer detailed descriptions of the church after which the earthquake was named, as well as for other churches, convents, schools, government buildings and hospitals that suffered different types of damage to towers, bell towers, walls, facades, doors and windows. The total number of damaged buildings identified with an actual address (at least street name) and therefore not including reports that mention «several houses in ruins or bad shape», was 210, with damage ranging from

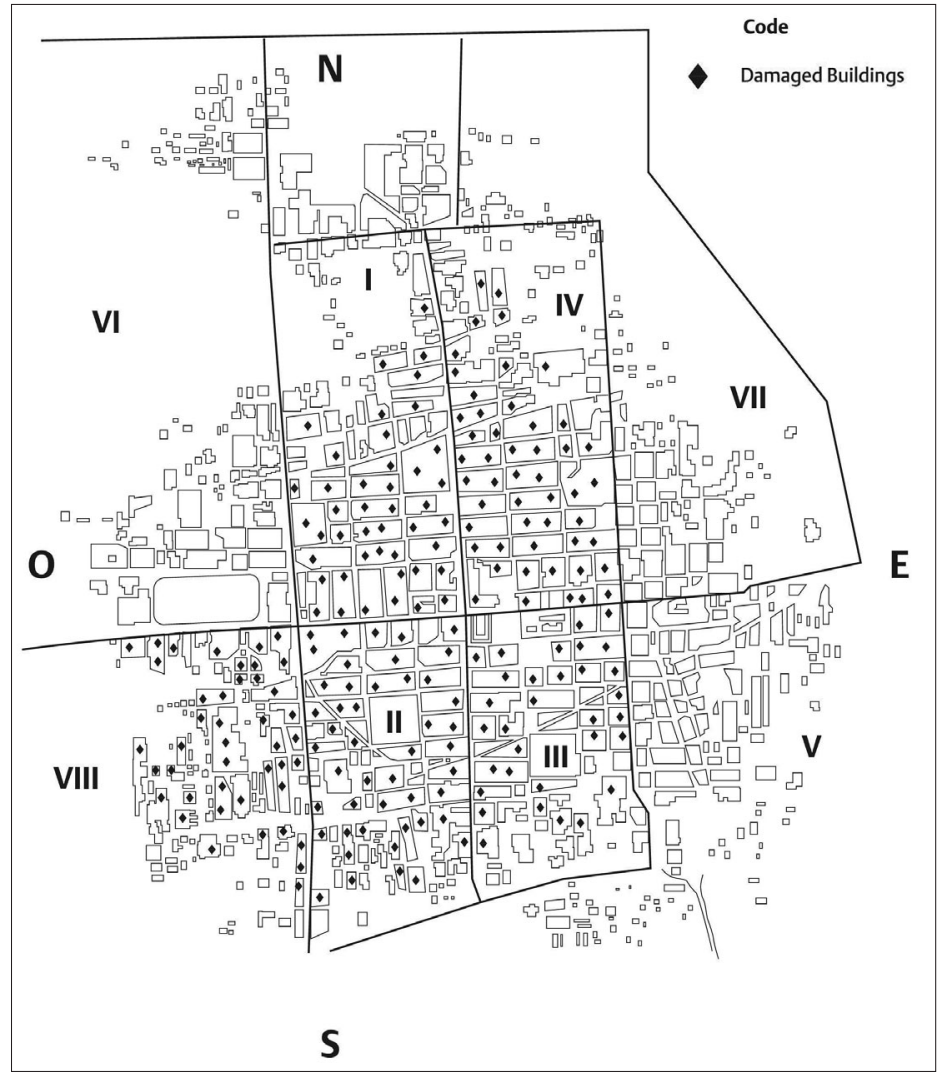

Fig. 3. Effects of the 7 April 1845 earthquake in Mexico City. 
slight cracks to collapsed inner and outer walls, towers and domes. In addition the earthquake affected main aqueducts that brought water into the city, bridges and city gates.

Figure 3 shows the first mapping of the effects of this earthquake in Mexico City. It is still necessary to identify the precise location of each building with its specific type of damage. Nevertheless this approach allows one to realise that the affected area is very similar to that of the 1800 earthquake, with a considerably higher number of buildings affected mainly in districts I, II, III, IV, and VIII.

Seventeen dead and injured were reported in Mexico City, a rather low figure considering the quake's intensity as well as its estimated magni- tude. As for the economic damage, reports were prepared by the relevant mayors describing in great detail the neighbourhoods affected. Newspapers, such as El Siglo Diez y Nueve (1845) and the Diario Oficial (1845) published the reports.

\subsection{8}

Even though only reports for five districts have been found for this earthquake, newspapers provide additional information on neighbourhoods not mentioned in archives. These considered districts VI and VIII to be disaster areas in, where many destroyed houses were reported. Historical documents and newspapers report

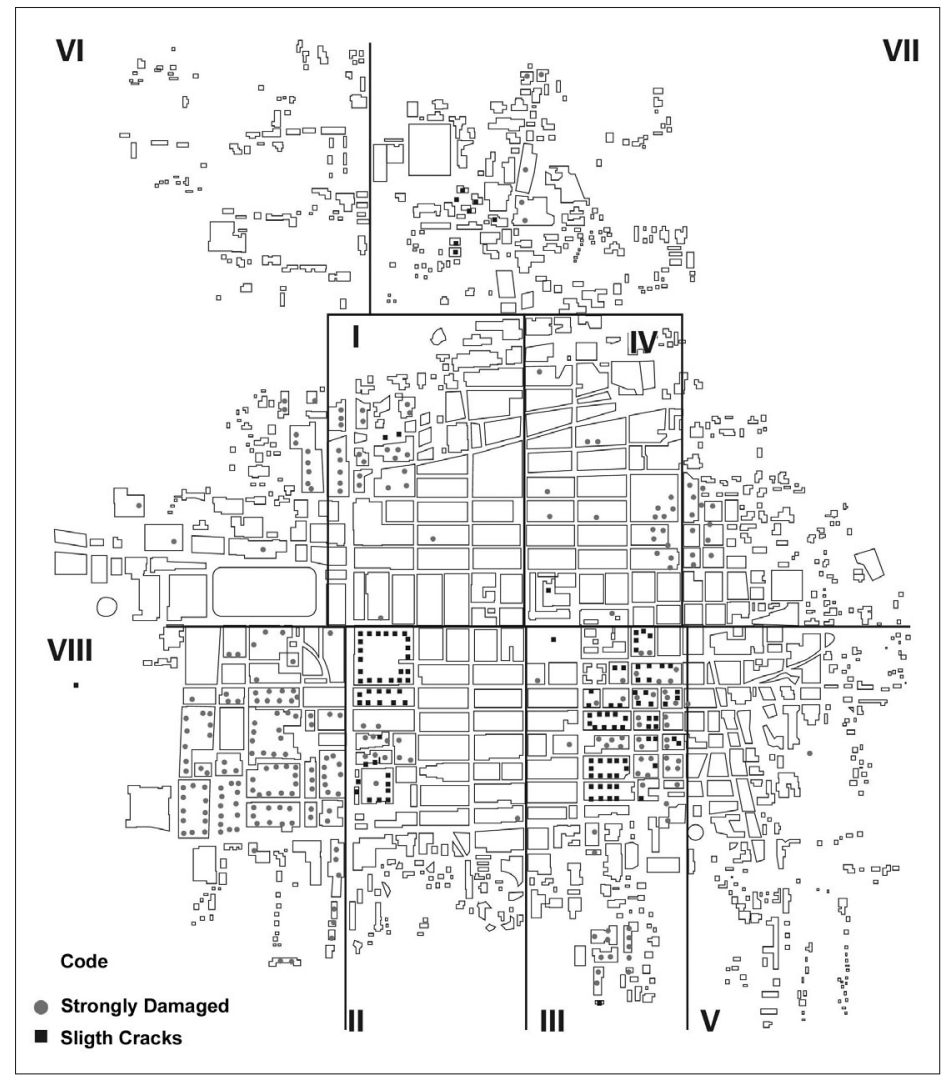

Fig. 4. Effects of the 19 June 1858 earthquake in Mexico City. 
damage to 31 public buildings, 106 cracked buildings and 63 in ruins in the city. The real figures must have been higher, for some districts offer only general comments, such as «in the neighbourhoods of San Cosme and Santa María, located in district VI, many buildings were damaged» (AHDF and El Siglo Diez y Nueve, 1858).

As compared to the north, east and western parts of the city, the most affected areas were the southwest and southeast. Damage was worse in district VIII, southward of the most important park in town, the Alameda Central, a very popular park even nowadays. This district registered high population growth in the 19th Century, and was mainly composed of urban and suburban housing quarters lacking public utilities. The population of VIII district was not only numerous, but also heterogeneous, as it included native peoples, craftsmen and some rich merchants. This becomes evident in the type of reports, some thoroughly describing the blocks close to main square, and the rest barely and carelessly mentioning peripheral blocks.

Districts I and IV, severely affected in 1800 , were not as damaged in 1858 , for there were not as many people or houses, although many public buildings were still in the area, mainly in district IV (fig. 4, originally published in Molina, 2001). Damage was caused to poor neighbourhoods in the outskirts, where streets were irregular and most of the housing consisted of shantytowns, including adobe quarters. As always, the press only made general comments on these poor areas. This lack of reports and of district mayors' visits reveals the limited access those inhabitants had to municipal assistance. The 1858 earthquake also affected the two main aqueducts in town: San Cosme and Salto del Agua, as well as some drainpipes.

\section{Conclusions}

The study of effects and impact throughout the country and particularly in Mexico City caused by the three strongest earthquakes recorded in early to mid 19th Century Mexico required a comparative focus that showed many constants and scattered changes. A comparative focus made it necessary to study in depth the historical contexts in which each quake occurred.

Comparison was also needed to evaluate the quality of available sources, i.e. to consider not only the amount of information, but also its type. The press has certainly been a relevant source for the historical analysis of earthquakes. Not only has it provided information on the impact of the three earthquakes studied here, but has also proved particularly valuable when establishing their geographical reach. Historical documentation coming from archives and primary historiographical bibliographical sources offered material related mainly to governmental actions dealing in particular with inspection and reconstruction, and this did not vary much from 1800 to 1858 . After each earthquake, architects and experts carried out visits to each one of the eight major districts of Mexico City, inspecting the state of each building. These reports allow us to draw figures for the Mexican capital and help to compare the level of damage in each neighbourhood affected by the earthquakes. The first four districts of the city, an area which represented the core of the urban development within the metropolitan zone, where a considerable number of commercial stores and housings had been established, and in which were located the principal buildings and a great number of housing, were the most affected by the 1800 and 1845 earthquakes. During the 1858 event the major district number VIII, south of la «Alameda Central», was the most affected.

There are more references to damage outside the capital in the case of the 1845 and 1858 earthquakes; for the 1800 one there are only few detailed references and only for the state of Oaxaca. In contrast, for the other two earthquakes several newspapers described in detail the localities affected. The 1858 earthquake is the most well documented of the three, if one takes the country as a whole, with a specific archival section that offered valuable information on the affected towns at the state Michoacán, nearest to the epicentre.

It is interesting to note that human losses during the three earthquakes were not high. In fact only two records mention deaths: Mexico 
City in 1845 (17 dead and injured) and Pátzcuaro in 1858 (21 deaths). The town of Huamuxtitlán was completely destroyed by the 1845 earthquake, yet no deaths were reported. This suggests that, compared to our times, the population was not as exposed to the effects of seismic activity. Population density and concentration were considerably lower. Some colonial buildings were perhaps more resistant; if houses were not as crowded, the collapse of adobe walls did not threaten people's safety so much.

It is without doubt that the intensity of the event that has remained less studied, the 7 April 1845, was the highest in Mexico in the first half of the 19th century, and maybe the highest before the 1985 event. It deserves a deeper investigation.

All the information related directly to the earthquakes needs to be completed and compared with that from other historical sources in order to understand the specific context in which each one occurred. In this case the three earthquakes occurred in a period when the quality and even quantity of records were quickly developing and increasing. It was the «Age of Enlightenment», the waking up of scientific explanations for natural phenomena, the gradual giving up of religious manifestations associated with hazards, and the beginning of a new era for understanding earthquakes and disasters.

\section{Acknowledgements}

A special acknowledgement to Paola Albini and Virginia García-Acosta, who revised the paper and made valuable comments and suggestions.

\section{REFERENCES}

Archival sources

AGNM (Archivo General de la Nación Mexico-Distrito Federal) (1800): Correspondencia de Virreyes, Gobernación Indiferente, Obras Públicas, Templos y Conventos.

AHDF (Archivo Histórico del Distrito Federal) (1800, 1845, 1858): Historia Temblores, Fincas, Edificios Ruinosos .

AHMCR (Archivo Histórico Manuel Castañeda Ramírez-
Michoacán) (1858): Negocios Diversos

AHMM (Archivo Histórico Municipal de Morelia-Michoacán) (1845, 1858): Actas de Cabildo, Libro de Sub-prefectura de Pátzcuaro.

APP (Archivo Parroquial de Pátzcuaro-Michoacán) (1845, 1858): Libro de Composturas.

\section{Newspapers}

Diario Oficial, 1845.

El Siglo Diez y Nueve, 1845, 1858.

Gacetas de México, 1800.

\section{Papers and monographs}

AdORNO, J.N. (1864): Memoria acerca de los terremotos en México escrita en octubre de 1864 por ... (Imprenta de Mariano Villanueva, Mexico).

Alfaro, M. (1906): Reseña Histórica-Descriptiva del Antiguo Hospicio de México (Imprenta del Gobierno Federal, Mexico)

Amerlinck, T. (1962): Sismos en la Ciudad de México; Ojeada Histórica (Editorial Luz, Mexico).

BösE, E. and J. GARcía (1908): El temblor del 14 de abril de 1907, in Parergones del Instituto Geológico de México, II $(4,5,6), 135-258$.

Bravo H., G. SuÁREZ and E. ZúÑIGA (1988): Potencial sísmico en México, in Estudios Sobre Sismicidad en el Valle de México (Departamento del Distrito Federal, Programa de las Naciones Unidas para el Desarrollo, Mexico), 1-31.

Bustamante, C.M. (1852): Los Tres Siglos en México Durante el Gobierno Español, Hasta la Entrada del Ejército Trigarante (Imprenta de J.R. Navarro, Mexico).

Castillo N., E. DEL (1875): México en el Siglo XIX, o Sea su Historia Desde 1800 Hasta la Época Presente (Editor E. Never, Mexico), 29 vols.

DicCIONARIO PORRÚa (1986): Historia, Biografía y Geografía de México (Porrúa, Mexico).

FigueroA A., J. (1963): Historia sísmica y estadística de temblores de las costa occidental de México, in Boletín Bibliográfico de Geofísica y Oceanografía Americanos (Mexico), III, 107-134.

Galván Rivera, M. (1950): Colección de efemérides publicadas en el calendario del más antiguo Galván; desde su fundación hasta el 30 de junio de 1950 (Antigua Librería de Murguía, Mexico).

García-Acosta, V. and G. SuÁrez Reynoso (1996): Los Sismos en la Historia de México (Universidad Nacional Autónoma de México, Centro de Investigaciones y Estudios Superiores en Antropología Social, Fondo de Cultura Económica, Mexico), vol. 1, pp. 718.

García Cubas, A. (1904): El Libro de Mis Recuerdos: Narraciones Históricas, Anécdotas y de Costumbres Mexicanas Anteriores al Actual Estado Social Ilustradas con más de Trescientos Fotograbados (Imprenta de Arturo García Cubas Hermanos sucesores, Mexico).

Gómez dE LA CoRTina, J. (1864): Terremotos, in E. MAS- 
son, Olla Podrida (Imprenta Hispanoamericana de Cosson y Ca., Paris).

LÓPEZ DE VILLASEÑoR, P. (1961): Cartilla Vieja de la Nobilísima Ciudad de Puebla (Universidad Nacional Autónoma de México, Mexico).

Malo, J.R. (1948): Diario de Sucesos Notables (18321864), arreglados anotados por el P. Mariano Cuevas S.J. (Editorial Patria, Mexico), 2 vols.

Márquez, I. (2001): El temblor del 8 de marzo de 1800, in Los Sismos en la Historia de México, edited by V. GARCíA-Acosta (Universidad Nacional Autónoma de México, Centro de Investigaciones y Estudios Superiores en Antropología Social, Fondo de Cultura Económica, Mexico), vol. 2, pp. 181-219.

Martínez GracidA, M. (1890): Catálogo de terremotos desde 1507 hasta 1885, in Cuadro Sinóptico, Geográfico y Estadístico de Oaxaca, ms.

MentZ, B. von (1980): México en el siglo XIX (Universidad Nacional Autónoma de México, Mexico)

MolinA, A. (2001): El sismo del 19 de junio de 1858, in Los sismos en la Historia de México, edited by V. GARcía-AcosTA (Universidad Nacional Autónoma de México, Centro de Investigaciones y Estudios Superiores en Antropología Social, Fondo de Cultura Económica, Mexico), vol. 2, pp. 223-263.

Munguía C., F. (1976): Panorama Histórico de Sayula, Capital de la Antigua Provincia de Ávalos, (Departamento de Bellas Artes del Gobierno de Jalisco, Guadalajara, Mexico)

OROZCO Y BERRA, J. (1887): Efemérides seísmicas mexicanas, Memoria de la Sociedad Científica «Antonio Alzate», I, 303-541.
PÉREZ, R. (1904): Efemérides Nacionales o Narración Anecdóticas de los Asuntos Más Culminantes de la Historia de Méjico (Tipografía y encuadernación «La Idea del Siglo», Mexico).

RAMíREZ, S. and V. REYES (1873): Informe sobre los temblores y volcanes del Agua Fría y Jaripeo con una lista de rocas y minerales, in Boletín de la Sociedad Mexicana de Geografía y Estadística, III. Época, I, 67-88.

RESÉNDIZ, A.S. (1988): Michoacán y su Litoral, Semblanza Socioeconómica (Morelia, Mexico).

Rivera Cambas, M. (1883): México Pintoresco, Artístico y Monumental (Imprenta de la Reforma, Mexico), 3 vols.

Romero, J.G. (1972): Michoacán y Guanajuato en 1860. Noticias para formar la historia y estadística del Obispado de Michoacán (Fimax, Mexico).

Salas León, A. (1941): Pátzcuaro. Cosas de Antaño y de Ogaño (Pátzcuaro, Mexico).

Sedano, F. (1880): Noticias de México, recogidas por... desde el año de 1756, coordinadas, escritas de nuevo y puestas por orden alfabético en 1800 con notas y apéndices del Presbítero V. de P.A. (Edición de la «Voz de México», Imprenta de J.R. Barbedillo y Ca., Mexico).

VÁzQUEZ, J. (2000): Los primeros tropiezos, in Historia General de México (El Colegio de México, Mexico), 547-548.

Waitz, P. (1920): El volcán de Jorullo. Calendario de Momo y Minerva para el año de 1859, Mexico 1858, Memorias de la Sociedad Científica "Antonio Alzate», XXXVII (4-6), 278-290.

ZAYAs, E. R. (1893): Los Estados Unidos Mexicanos, sus condiciones naturales (Oficina Tipográfica de la Secretaría de Fomento, Mexico). 